\title{
PERUBAHAN NILAI DAN FILOSOFIS BUSANA KEBAYA DI JAWA TENGAH
}

\author{
Ratna Endah Santoso ${ }^{1)}$, Theresia Widyastuti ${ }^{2)}$, Tiwi Bina Affanti ${ }^{3)}$, \\ Adji Isworo Josef ${ }^{4)}$, LV Ratna Devi Sakuntalawati ${ }^{5)}$ \\ Fakultas Seni Rupa dan Desain Universitas Sebelas Maret \\ Fakultas IImu Sosial dan Politik Universitas Sebelas Maret \\ cezaraesa@gmail.com ${ }^{1}$
}

\begin{abstract}
ABSTRAK
The Javanese who live in the Central Java region are known for their cultural strength. This can be seen from how they uphold the heritage traditions of their ancestors. Besides that, Central Javanese people are easily known through their typical costume. Kebaya and its equipment from head to toe, it is said that initially only used by the royal community had a quite interesting value and philosophy. For decades kebaya as part of history, experienced various changes in line with the era that continues to run. The most important thing is that kebaya is no longer an everyday outfit like in the past.

This research paper uses qualitative research using a cultural approach. This study aims to find out (1) changes in values and philosophies such as what happened to kebaya clothing specifically used in the Central Java region; (2) whether today's kebaya can still be called traditional clothing, especially with various changes caused by current conditions.
\end{abstract}

Keywords: kebaya, fashion, philosophical value,

\begin{abstract}
ABSTRAK
Suku Jawa yang mayoritas mendiami wilayah Jawa Tengah dikenal dengan kekuatan budayanya. Hal ini tampak dari bagaimana mereka menjunjung tinggi tradisi warisan nenek moyangnya. Selain itu orang Jawa Tengah mudah dikenal melalui busana khas kebayanya. Kebaya beserta perlengkapannya dari ujung kepala hingga ujung kaki, konon awalnya hanya digunakan oleh kalangan kerajaan saja mempunyai nilai dan filosofis yang cukup menarik. Selama berpuluh tahun kebaya sebagai bagian dari sejarah, mengalami berbagai perubahan sejalan dengan jaman yang terus berjalan. Hal terpenting bahwa kebaya saat ini bukan lagi menjadi pakaian sehari-hari seperti dahulu kala.

Riset paper ini menggunakan bentuk penelitian kualitatif dengan menggunakan pendekatan budaya. Penelitian ini bertujuan untuk mengetahui (1) perubahan nilai dan filosofi semacam apa yang terjadi pada busana kebaya khususnya yang digunakan di wilayah Jawa Tengah; (2) apakah kebaya masa kini masih bisa disebut pakaian tradisional terutama dengan berbagai perubahan yang disebabkan dengan kondisi masa ini.
\end{abstract}

Kata kunci: kebaya, busana, nilai filosofi,

\section{PENDAHULUAN}

Kebaya biasanya dilengkapi dengan kain panjang batik, stagen, selen- dang. Sementara pemakainya menggunakan sanggul dengan bentuk sanggul yang disesuaikan dengan usianya. Ko- 
non kebaya awalnya hanya digunakan oleh kalangan karaton di Solo dan Yogya -karta ini dipakai dalam keseharian maupun acara resmi. Busana ini mempunyai nilai dan filosofis yang cukup menarik. Pemakaian kebaya umumnya pada acara-acara resmi, salah satunya acara perkawinan. Dalam kesempatan semacam itu dapat dilihat berbagai inovasi busana kebaya yang cukup menarik. Dapat dikatakan bahwa terjadi berbagai 'penambahan' atau dapat juga disebutkan sebagai 'pengurangan' dalam berkebaya jika dibandingkan dengan kebaya di jaman dahulu (Pentasari, 2005). Beberapa bagian yang dahulu termasuk kelengkapan dari kebaya dan bahkan memiliki makna filosofi tersendiri; saat ini seperti hilang atau bahkan terabaikan oleh perkembangan cara berpakaian di Indonesia.

Fenomena menarik yang terjadi pada busana kebaya atau pakaian kebaya beserta perlengkapannya ini menjadi ide awal dari diadakannya penelitian tentang kebaya. Kebaya berkaitan dengan tekstil. Tekstil diaplikasikan sebagai bagian dari busana, salah satunya kebaya yang bukan saja sebagai pakaian khas perempuan Jawa tetapi juga sudah dicanangkan sebagai busana nasional. Awalnya perempuan Jawa hanya menggunakan batik atau kain panjang yang menutupi bagian pinggang hingga kaki. Lalu ditambahkan dengan selembar kain batik lain untuk menutupi bagian dada, yakni mulai bawah ketiak hingga pinggang yang disebut sebagai kemben. Bagi perempuan kebanyakan yang bukan berasal dari kalangan ningrat sudah terbiasa memakai pakaian dengan bahu terbuka semacam ini.

Berbeda dengan perempuan dari kalangan bangsawan, yang menutupi bagian bahunya dengan menambahkan blus di atasnya. Umumnya blus dengan lengan panjang dan tersebut tanpa kancing, sehingga bagian mukanya cukup ditautkan dengan peniti. Dalam perkembangannya perempuan bukan ningrat pun memakai kebaya semacam ini tetapi cara menggunakannya tidak menutup bagian depan dengan rapat, sehingga kembennya masih dapat terlihat.

Model ini menjadi ide bagi munculnya kebaya berkutubaru, yaitu selembar kecil kain dari bahan yang sama dengan bahan kebaya, yang dipasang tepat di depan dada menghubungkan kedua tepi ke-baya bagian depan. Kutu baru atau disebut juga sebagai bef ini menjadi pengganti kemben. Sementara pada bagian pinggang biasanya digunakan stagen yang ditutupi dengan kain, misalnya jumputan.

Bentuk dasar kebaya berupa blus lengan panjang ini mengikuti bentuk tubuh, sehingga pemakainya tampak anggun. Secara keseluruhan bantuk kebaya sama di setiap daerah, tetapi ada bebera 
-pa variasi yang ditambahkan, sehingga memberi ciri khas yang berbeda antara satu tempat dengan tempat lainnya. Di daerah pedalaman potongan bagian bawah depan kebaya biasanya lurus, sementara di daerah pesisir bagian bawah bagian depan kebaya ada yang lurus dan ada yang meruncing ke bawah. Biasanya bentuk ini digunakan oleh orang - orang keturunan Cina yang tinggal di kota-kota pesisir, seperti Pekalongan, Semarang. Sedangkan di kota Jepara dikenal dengan kebaya Kartini yang bentuknya mirip kebaya di Solo dan Yogyakarta, namun tanpa menggunakan kutubaru. Sementara kebaya kutubaru menjadi kebaya khas Jawa Tengah.

Adanya perubahan yang terjadi pada kebaya tidak terlepas dari perubahan jaman yang berkaitan dengan mode, dan beberapa hal lain yang berdampak pada pemakaian baju tradisional ini, seperti masalah sosial, budaya, politik, dan agama yang marak di tengah masyarakat. Jika dahulu pemakaian kebaya dilengkapi dengan segala sesuatu mulai dari ujung kepala hingga ujung kaki yang masing-masing mempunyai makna dan filosofinya sendiri, maka sekarang kebaya tetap dipakai dengan cara yang berbeda. Beberapa kelengkapan digantikan hal lain yang mungkin bermakna tetapi bukan dari sudut budaya Jawa. Perubahan inilah yang menarik untuk diteliti mengingat kebaya merupakan salah satu peninggalan nenek moyang yang menjadi ciri khas bangsa Indonesia dan harus tetap dilestarikan.

Jenis penelitian ini adalah penelitian deskriptif kualitatf, yang mampu memberikan uraian mengenai gejala perubahan nilai dan filosofis busana kebaya, berdasarkan pada indikatorindikator. Model penelitian yang dipilih adalah Naturalistic Inquiry. Model ini adalah kombinasi teknik-teknik survei dengan pendekatan naturalistik untuk mengembangkan pendekatan participant observation dalam fieldworknya. Paradigma naturalistik bersifat multiple constructed dan holistic. Hubungan antara peneliti dan yang diteliti bersifat interaktif. Seluruh entitas adalah dalam keadaan hubungan yang bersifat timbal balik. Dalam hal nilai, penyelidikan "terkait nilai". Jadi bukan "bebas nilai".

Oleh karena itu dalam penelitian ini peneliti menggunakan bingkai alami (natural settings) sebagai sumber utama. Selain itu peneliti menjadi instrumen kunci dalam mengumpulkan dan menafsirkan data, dan berusaha mendeskripsikan temuan. Dalam hal ini setiap orang yang dipelajari dipandang sebagai partisipan, konsultan atau kolega yang bekerjasama dengan peneliti. Keberadaan mereka adalah sebagai 'subyek. Melalui mereka hal utama adalah untuk dicari 'makna' yang dimilikinya agar dapat dipelajari hal yang mendasarinya. Seluruh 
analisis naturalistic inquiry bersifat induktif.

Penelitian ini dilakukan di wilayah Propinsi Jawa Tengah dan Daerah Istimewa Yogyakarta. Khususnya Jawa Tengah dipilih dua kelompok wilayah yakni pedalaman dalam hal ini Surakarta, dan pesisir, yaitu Semarang dan Jepara. Pemilihan Jepara terkait dengan kebaya Kartini yang menjadi kekhasan kota kelahiran Ibu Kartini ini. Penelitian ini ber -tujuan untuk mendeskripsikan perubahan dan nilai filosofi yang terjadi pada busana kebaya khususnya yang digunakan di wilayah Jawa Tengah, dan mendeskripsikan kebaya masa kini serta mengetahui apakah jenis ini masih dapat disebut sebagai pakaian tradisional terutama dengan adanya berbagai perubahan yang disebabkan kondisi masyarakat saat ini.

\section{PEMBAHASAN}

Busana Kebaya adalah pakaian tradisional yang dikenakan oleh wanita Indonesia yang dibuat dari kain kasa yang dikenakan dengan sarung, batik, atau pakaian tradisional yang lain seperti songket dengan motif warna-warni. Kebaya berbentuk blus sederhana dengan lengan panjang ini, konon berasal dari $\mathrm{Ci}$ -na yang kemudian menyebar ke wilayah Malaka, Sumatera, Jawa, Bali, dan Sulawesi. Hal ini menunjukkan bahwa kebaya sebenarnya bukan hanya di Jawa saja. Namun khususnya kebaya di Jawa Tengah mempunyai ciri tersendiri yang dapat membedakannya dengan kebaya di daerah lain.

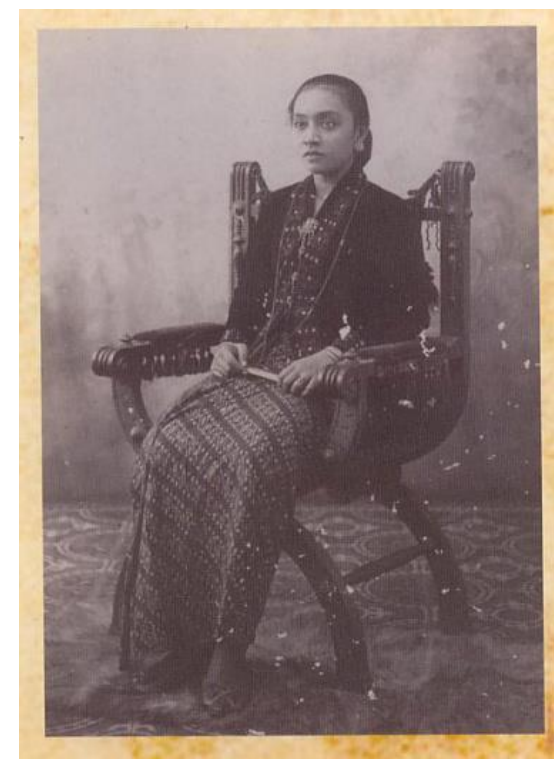

Gambar 1.

R.A Soerjadiati, putri dari KRT Mangoenjo IV, mengenakan kain kebaya beludru hitam.

Sumber:

Suryatini N. Ganie, seperti dikutip Alberthiene Endah, 2010. Eksplorasi Kreativitas Dua dasa Warsa Anne Avantie)

\section{Kebaya biasanya dipadukan} dengan batik atau kain panjang yang membebat tubuh mulai dari pinggang hingga ke mata kaki. Kain yang dipakai dengan cara meliliti tubuh seperti ini membuat pemakainya sulit untuk bergerak cepat, dan hal ini menyebabkan identik dengan pribadi yang lemah gemulai. Disamping itu, bagi perempuan Jawa kebaya tidak hanya sebagai pakaian saja tetapi juga menyimpan sebuah filosofi yang mengandung arti nila-nilai kehidupan. Salah satunya ada- 
lah nilai kehalusan, kesabaran, dan kesederhanaan. Hal ini tampak dari modelnya yang sederhana, pemakaiannya yang mengharuskan pemakai kebaya bergerak perlahan, dan perlengkapan yang menyertainya menyebabkan perem -puan yang berbusana kebaya tampak anggun.

Dahulu baik para bangsawan maupun rakyat biasa mengenakan kebaya, entah itu untuk kegiatan sehari-hari atau untuk keperluan upacara adat; dilengkapi dengan stagen atau kain yang panjangnya antara tiga sampai lima meter dan lebar tidak lebih dari 20 puluh sentimeter yang dililitkan di seputar perut, dan ditambahkan kain selendang untuk mempercantik penampilan. Sekarang orang memilih memakai korset yang mudah dipakai sebagai pengganti stagen. Selain itu rambut yang dahulu disanggul dan menambahkan tusuk konde atau hiasan sudah tergantikan dengan jilbab atau rambut yang ditata sedemikian sebagai pengganti konde. dan memakai berbagai perhiasan lain, seperti subang (anting), cincin, kalung, dan gelang. Secara keseluruhan busana kebaya mampu menjadi busana tradisional yang bisa dipakai sehari-hari atau di setiap acara resmi.

Dapat dikatakan busana kebaya selalu berubah setiap waktu sesuai dengan mode yang sedang trend. Oleh sebab itu tidak heran jika saat ini bentuk dan pemakaian kebaya sudah banyak mengalami perubahan sesuai kondisi. Dilihat dari bentuk misalnya, kebaya memiliki bentuk yang tidak lagi lekat dengan tubuh. Sementara dari cara pemakaiannya, kebaya masa kini sering dipadukan dengan yang bukan kain panjang batik, seperti misalnya rok, celana panjang, bahkan jeans. Perubahan ini tidak saja secara visual melainkan juga secara nilai. Di dalam masyarakat pasti mengalami perubahan, yang dapat mengenai perubahan nilai-nilai sosial, norma-norma sosial, pola-pola perilaku organisasi, lapisan-lapisan masyarakat, susunan lembaga kemasyarakatan, kekuasaan, wewenang, interaksi sosial, dan lain sebagainya. Nilai merupakan sesuatu yang mempengaruhi perilaku manusia. Perubahan muncul karena aspek potensial masyarakat sendiri dan datang dari luar.

Ogburn (cit. Garna, 1992) mekatakan, perubahan sosial yang termasuk didalamnya perubahan budaya atau kebudayaan mengacu pada perubahan dalam mekanisme pergaulan manusia. Budaya dibangun oleh komponen nilai yang dipegang dan norma yang dianut masyarakat. Nilai adalah pandangan yang sifatnya abstrak dan ideal sedangkan norma adalah seperangkat prinsip atau aturan yang memainkan peran dalam menyusun tatanan masyarakat (Giddens, 1989). Maka jika terjadi perubahan 
budaya itu berarti terjadi perubahan nilai dan norna yang dipegang masyarakat. Dalam kehidupan yang makin lama makin bersifat global, perubahan itu akan dianggap suatu kebiasaan karena perkembangan teknologi dan komunikasi yang cepat.

Kebaya mungkin hanya terlihat sebagai sehelai pakaian sederhana, tapi justru di balik kesederhanaan itu tersimpan makna yang sangat mendalam. Modelnya yang sederhana mencerminkan kesederhanaan masyarakat Indonesia. Dalam filosofi Jawa, kesederhanaan juga berkaitan dengan sifat kesabaran. Potongannya yang melekat mengikuti bentuk tubuh menggambarkan bahwasanya perempuan harus dapat selalu menyesuaikan diri dengan keadaan, dan sekaligus mampu menjaga diri sendiri. Secara keseluruhan, kebaya menjadi lambang nilai-nilai yang diharapkan dari seorang perempuan, yaitu beradaptasi, luwes, lemah lembut, sabar, dan mandiri dalam menjaga diri sendiri (Astarini, 2018).

Penggunaan busana kebaya tidak hanya di kalangan wanita bangsawan saja tetapi juga kalangan rakyat biasa juga menggunakannya (Titaharis, 2018). Memakai kebaya dengan bawahan jarik atau kain panjang merupakan perlambang sifat dan tampilan perempuan yang lemah gemulai. Lilitan kain yang ketat akan membuat perempuan sulit bergerak, sehingga hal itu 'memaksa' mereka untuk bergerak dalam kehalusan dan gerak-gerik nan lembut. Filosofinya ialah seorang perempuan haruslah lembut dalam tutur kata, halus dalam bertindak. Selain itu, adanya stagen yang berfungsi sebagai ikat pinggang menyimbolkan usus yang panjang atau kesabaran yang tinggi. Budaya berkebaya yang sudah dilakukan sejak jaman dahulu kala merupakan salah satu bukti bahwa bangsa ini sudah memiliki budaya yang berlandaskan keindahan. Menurut Peter Berger, kebudayaan adalah produk manusia, produk itu lalu menjadi kenyataan obyektif yang kembali mempengaruhi yang meng hasilkan busana kebaya menjadi pakaian yang dipakai diberbagai kesempatan.

Leslie White mendefinisikan kebudayaan sebagai "suatu kumpulan gejala-gejala yang terorganisir yang terdiri dari tindakan-tindakan (pola perilaku), benda-benda (alat-alat; atau benda-benda yang dibuat dengan alat-alat), ide-ide (kepercayaan, pengetahuan), dan perasaan-perasaan (sikap-sikap, nilai-nilai) yang semuanya itu tergantung pada penggunaan simbol-simbol (Leslie White cit. Lawang, 1985). Kebudayaan tidak hanya mencerminkan kenyataan yang bersifat obyektif, tetapi juga mencerminkan kenyataan subyektif berupa simbolsimbol. Simbol adalah khas manusia; simbol mencerminkan usaha manusia 
untuk mengerti kenyataan sosial yang dihadapinya, dan membuatnya berarti untuk dia sendiri (Lawang, 1985). Demikian juga dengan busana kebaya yang menjadi kajian dalam penelitian ini, merupakan simbol yang mengungkapkan dan merumuskan perasaan, yang sesuai dengan lingkungan dan muncul dari ideide dan pengetahuan manusia. secara keseluruhan dalam setiap perubahan bentuknya, kebaya tidak pernah pergi dari akar bentuknya sejak awal yang sederhana. Busana ini bisa dipakai mulai dalam kegiatan sehari-hari yang sederhana sampai acara yang bersifat mewah.

$\mathrm{Hal}$ ini senada dengan yang dinyatakan oleh Koentjaraningrat (2000), bahwa kebudayaan sebagai keseluruhan gagasan dan karya manusia, yang dibiasakannya dengan belajar, beserta keseluruhan dari hasil budi dan karya. Dari dua definisi (Liesli White dan Koentjaraningrat) menunjukkan bahwa kebudayaan adalah produk manusia (keseluruhan gagasan dan karya manusia), yang didalamnya terkandung nilai dan norma. Nilai erat kaitannya dengan kebudayaan dan masyarakat. Setiap kebudayaan memiliki nilai tertentu mengenai sesuatu. Nilai adalah gambaran mengenai apa yang diinginkan, yang pantas, yang berharga, yang mempengaruhi perilaku sosial dari orang yang memiliki nilai itu. Kebudayaan dan masyarakat itu sendiri merupakan nilai yang tak terhingga bagi orang yang memilikinya (Lawang, 1985).

Sejak masuknya pengaruh berbusana dengan latar belakang agama, kebaya tetap digunakan dengan cara yang berbeda. Ada yang dihilangkan seperti perlengkapan pada bagian kepala, tetapi ada yang dimunculkan dengan nilai estetika yang baru sesuai dengan kepercayaan yang dianut oleh masyarakat. Semua ini berkaitan dengan orientasi nilai budaya yang diperlukan untuk mengembangkan diri dan masyarakatnya. Orientasi nilai menunjuk pada standar-standar normatif yang mempengaruhi dan mengendalikan pilihanpilihan individu terhadap tujuan yang dicapai dan alat yang dipergunakan untuk mencapai tujuan itu (Lawang, 1985). Unsur yang terkandung dalam masalah-masalah yang terkait dengan sistem nilai budaya adalah, pengetahuan ( tentang $\mathrm{HH}, \mathrm{HM}$ ), sikap (pada $H K, H A, H M$ ) dan pola perilaku (yang terbangun dalam $\mathrm{HW}, \mathrm{HM})$, yang ada dalam masyarakat.

Unsur-unsur tersebut sesuai dengan definisi yang dikemukakan oleh Ralp Linton (cit. Nurdien, 1983) bahwa budaya adalah jumlah total dari pengetahuan, sikap dan pola perilaku kebiasaan yang dibagi dan ditransmisikan oleh anggota masyarakat tertentu. Jika penelitian megunakan pendekatan budaya, atau dengan menggunakan cara pandang buda- 
ya, yang meliputi konsensus dalam hal pengetahuan, pola tingkah laku dan sikap atau dalam hal sistem norma dan nilai pada umumnya (Nurdien, 1983). Konsensus ini hanya dapat ditemui dalam kegiatan-kegiatan organisasi sosial dan ekonomi, ilmu pengetahuan dan teknologi, serta proses simbolis yang merupakan kreativitas manusia (Kuntowijoyo, 1999). Beberapa hal yang hilang khususnya dalam berbusana kebaya, digantikan oleh hal-hal lain yang berusaha menggantikan apa yang dihilangkan. Pada kebaya masa kini, jilbab tidak lagi hanya sebagai penutup kepala dengan alasan untuk menutupi aurat; tetapi juga ditata sedemikian rupa seperti menggantikan tata rambut. Oleh sebab itu muncul berbagai model jilbab yang dalam hal ini adalah penutup kepala digunakan dengan cara membuat modelmodel menyerupai konde atau kepangan rambut.

Sesuai dengan zaman yang terus berkembang, jilbab masuk ke dalam bagian mode di Indonesia yang berkembang dengan cepat. Bahkan jilbab menjadi salah satu kelengkapan penting dalam setiap penampilan perempuan Muslim, termasuk ketika menggunakan kebaya. hadirnya jilbab menggeser keberadaan asesoris di bagian kepala, yakni sanggul dan asesorisnya. Oleh sebab itu jika berbicara mengenai "busana kebaya", yakni kebaya beserta per- lengkapannya; maka di jaman dahulu kebaya dilengkapi dengan jarit atau kain panjang batik, stagen, selendang, ditambah dengan asesoris mulai dari kepala, yaitu yang menghiasi sanggul, hingga asesoris lain seperti anting, bros, kalung, gelang, dan cincin. Sementara di jaman sekarang "busana kebaya" adalah kebaya dan jilbab yang dilengkapi kain panjang dan sarung. Simbol yang selama ini melengkapi busana kebaya berubah secara penampilan sekaligus maknanya.

Sebenarnya kerudung atau jilbab sudah ada di Indonesia sejak kurang lebih abad ke-17. Hal ini dapat dilihat pada pakaian yang digunakan perempuan di Aceh. Bahkan di masa lalu, seorang perempuan yang berkebaya dilengkapi dengan sanggul pun sering menggunakan selendangnya sebagai kerudung. Penampilan perempuan berkebaya, bersanggul, dan berkerudung selendang ini merupakan salah satu ciri yang khas pada perempuan di masa lampau. Meskipun berkerudung tetapi peran sanggul sebagai pelengkap kebaya masih dapat terlihat. Dari paparan Liesli White, Koentjaraningrat dan Lawang dapat dikatakan bahwa, kebudayaan berkaitan dengan simbol-simbol yang merupakan eksistensi diri manusia. Simbol adalah produk manusia yang didalamnya terkandung nilai dan norma, yang selanjutnya akan mempengaruhi 
perilaku sosial orang yang memiliki nilai itu. Konsepsi-konsepsi yang dianggap amat bernilai dalam hidup, merupakan sistem nilai budaya yang berfungsi sebagai pedoman tertinggi bagi kelakuan manusia.

Para perempuan Jawa melengkapi busana kebayanya dengan menggelung rambutnya dan menjadi sanggul atau konde. Selain sanggul atau konde adalah tatanan riasan rambut juga memiliki makna dan filosofi tersendiri. Menurut seorang guru besar dari Universitas Indonesia makna yang terkandung dalam sanggul merupakan penggambaran seorang perempuan yang pandai menyimpan rahasia. Dalam kerangka Kluckhohn (Koentjaraningrat, 2000) masalah-masalah yang terkait dengan sistem nilai budaya adalah masalah dasar dalam hidup, yaitu 1) hakekat hidup manusia (HH). 2) hakekat karya manusia (HK). 3) hakekat kedudukan manusia dalam ruang dan waktu (HW). 4) hakekat manusia dengan alam sekitarnya (HA). 5) hakekat hubungan manusia dengan sesamanya (HM).

Dilihat dari sisi hijab, maka jilbab memiliki maknanya yang dalam bagi seorang perempuan Muslim, yakni sebagai bentuk memproteksi diri dari berbagai gangguan dan godaan. Ada beberapa cara mencari hubungan antara simbol dan masyarakat. Menurut Mann- heim (1936 cit. Kuntowijoyo, 1999), karena ada dorongan pikiran tentang struktur dan superstruktur. Struktur berkaitan dengan bagian-bagian yang saling tergantung dan membentuk pola tertentu. Bagian dari sesuatu tersebut terdiri atas pola perilaku, individu maupun kelompok, institusi maupun masyarakat. Superstruktur berkaitan dengan nilai, cita-cita, simbol-simbol ekspresif (yang mampu memberikan gambaran, keinginan maupun gagasan) (Kuntowijoyo, 1999). Struktur dan superstruktur tidak secara langsung dapat dikaitkan, melainkan melalui jaringan yang komplek, salah satunya adalah psikologi. Keterlibatan kompleksitas kejiwaan mempengaruhi pembentukan imajeri, yang karena adanya kepentingan sosial, mampu menciptakan simbol-simbol yang dibutuhkan masyarakat dari berbagai golongan.

Menurut Ibu Suyati Tarwo Sumosutargio dalam wawancara di Solo (Senin, 25 Februari 2019), menggunakan kebaya secara tradisional yang asli dilengkapi dengan sanggul merupakan hal kepantasan bagi seorang dari suku Jawa. Pendapatnya tentang bagaimana sebaiknya mengenakan kebaya adalah sebagai berikut: “....sebagai layaknya seorang perempuan Jawa yang berpenampilan secara pantas dan menghargai budaya sendiri (disawang-sawang jik pantes). Menggunakan kebaya lengkap 
dari kepala hingga kaki merupakan bagian dari kesopanan ala Jawa. Selain untuk menghormati orang-orang di sekitar kita juga menghormati diri sendiri di tengah masyarakat luas. Dengan memakai kebaya dan jarit sesuai aturan yang sudah ada sejak jaman dahulu, setiap perempuan Jawa akan berperilaku dan bergerak dengan lebih hati-hati dan perlahan...".

\section{SIMPULAN}

Penggunaan kebaya di Jawa Tengah saat ini telah banyak mengalami perubahan yang disebabkan adanya perubahan jaman yang berlatar belakang budaya modern, politik, dan agama. Mode yang sudah dikenal sejak berabadabad yang lalu, setiap saat mengalami perubahan di setiap waktu. Berawal dari pakaian sederhana untuk kebutuhan sehari-hari dan dibuat dari bahan alam yang dapat ditemukan di sekitar manusia. Di samping pembuatan tekstil untuk kebutuhan keseharian, manusia juga membuat tekstil untuk keperluan ritual berdasarkan kepercayaannya yang dipakai dalam upacara ritual terkait dengan daur hidupnya. Untuk kebutuhan inilah pakaian memiliki makna dan filosofi khusus sesuai dengan kepercayaan yang dianut.

Seiring dengan perkembangan peradaban manusia, maka cara berpakaian pun semakin berubah dan menjadi lebih baik dan lebih baik lagi dari sebelumnya. Bahkan tidak cukup secara penampilan, pemakaian pakaian termasuk pemakaian kebaya pun mengalami perubahan tidak terkecuali perubahan nilai dan filosofinya. Pakaian yang awalnya dibuat untuk menutupi tubuh, berkembang menjadi untuk kebutuhan penunjuk status. Selanjutnya pakaian juga sebagai bagian dari komoditas yang terkait dengan kebutuhan pasar. Jenis tekstil semacam ini tidak lagi memiliki makna filosofi melainkan lebih pada pemikiran yang bersifat ekonomis. Perubahan dari kebutuhan ritual menuju kebutuhan pasar ini berdampak pada visual kebaya yang dapat dilihat saat ini.

Sampai dengan saat ini, yang dimaksud dengan kebaya adalah blus tradisional perempuan yang digunakan di berbagai tempat di Nusantara tidak terkecuali Jawa. Khususnya di Jawa Tengah dikenal kebaya dengan kutubaru yang dipadukan dengan kain panjang batik atau jarit, baik dengan maupun tanpa kutubaru. Bahwasanya ada beberapa perubahan di bagian perlengkapannya maka kebaya masih dapat disebut sebagai busana tradisional asalkan dengan bentuk yang masih asli yakni blus berlengan panjang dan bentuk yang melekat pada tubuh. Namun jika dilihat dari mode yang berkembang di Indonesia, khususnya mode dengan latarbelakang agama maka bentuk me- 
lekat pada tubuh tidak diperkenankan. Maka muncul berbagai bentuk blus longgar yang semakin jauh dari bentuk asli kebaya. Jika hal ini terjadi, maka bentuk baru in tidak lagi dapat disebut sebagai kebaya tetapi lebih tepat disebut sebagai blus longgar.

\section{DAFTAR PUSTAKA}

Astarini. D. 2018. Kebaya Simbol Kelembutan dan Keteguhan Perempuan

https://merahputih.com/post/read /kebaya-simbol-kelembutan-danketeguhan-perempuan

Berger, P. Thomas Luckmann. 1989. The Social Construction of Reality. England: Penguin Books Ltd.

Giddens, A. 1989. Sociology. Cambridge: Polity Press

Karyaningsih, E. Faktor-Faktor yang Mempengaruhi Pemilihan Kebaya pada Ibu-lbu dan Remaja Putri. Jurnal Keluarga, Volume 1 Nomor 1 Februari 2015.

Koentjaraningrat. 2000. Kebudayaan, Mentalitas, dan Pembangunan. Jakarta: Penerbit Gramedia.

Kuntowijoyo. 1999. Budaya \& Masyarakat. Yogya: PT. Tiara Wacana.

Lawang, Robert M.Z. 1985. Pengantar Sosiologi. Jakarta: Departemen Pendidikan dan Kebudayaan Universitas Terbuka.

Lawang, Robert M.Z. 1985. Sistem Sosial Indonesia. Jakarta: Departemen Pendidikan dan Kebudayaan Universitas Terbuka.
Nurdien, HK. 1983. Perubahan Nilai-Nilai di Indonesia. Bandung: Penerbit Alumni

Pentasari, R. 2005. Chic in Kebaya. Jakarta: Penerbit Erlangga.

Setiawan, F. 2010. 50 Galeri Kebaya Eksotik nan Cantik. Jakarta: Penerbit Penebar Swadaya, 2010)

Sutopo. HB. 2002. Metode Penelitian Kualitatif. Surakarta: Sebelas Maret University Press.

Titaharis. 2018. Makna dan

Filosofi Kebaya https://titaharis.wordpress.com/2 018/01/04/makna-dan-filosofikebaya/

Triyanto, 2011. Eksistensi Kebaya dari Masa ke Masa. Klaten: PT Intan Sejati.

\section{Sumber lain:}

https://sulteng.antaranews.com/berita/40 707/ini-makna-di-balik-sanggul 